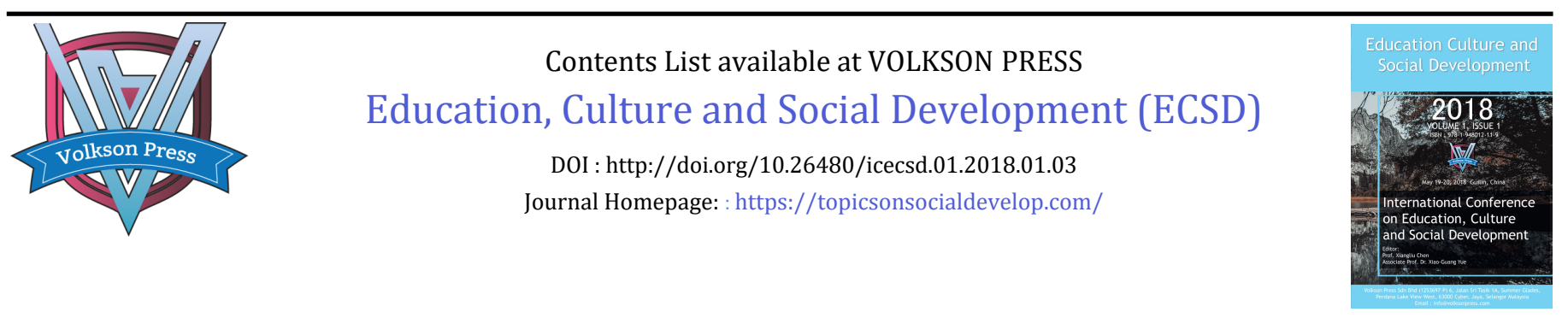

\title{
CAUSES AND COUNTERMEASURES OF FINANCING DIFFICULTIES FOR SMALL AND MEDIUM-SIZED ENTERPRISES
}

\author{
Qi Wujing \\ Wuhan University of Technology, Wuhan \\ *Corresponding Author Email: $344358996 @ q q . c o m$
}

This is an open access article distributed under the Creative Commons Attribution License, which permits unrestricted use, distribution, and reproduction in any medium, provided the original work is properly cited

\section{ARTICLE DETAILS}

\section{Article History:}

Received 12 November 2017 Accepted 12 December 2017 Available online 1 January 2018

\begin{abstract}
As an important composition of Chinese economy, Small and medium-sized enterprises (SMEs) play an increasingly important role in the economic structure of our country and provide sufficient opportunities for Chinese commodity market and employment market. However, with limited capability of SMEs, limitation of social environment and imperfectness of legal system, financing problem has become the most serious problem that restricts the survival and development of SMEs in China. I In order to solve the problem of financing for SMEs and promote the development of SMEs, this paper firstly introduces the concept of SME and current financing channels, and then proposes and analyzes the corporate guarantee problem, financing demand problem of financing institutions and imperfectness problem of legal system during the financing process of Chinese SMEs. According to what is mentioned above, it is recommended to improve SMEs' own assets accumulation ability, establish credit guarantee system and set up special bank service for SMEs to ease the financing difficulties for SMEs.
\end{abstract}

\section{KEYWORDS}

Small and medium-sized enterprises, Financing, Legal System, Credit Guarantee System

\section{INTRODUCTION}

Small and medium-sized enterprises (hereinafter referred to as SMEs) are a concept comparing to large enterprises. In different countries, influenced by different economic development level, cultural background, industry factors and other factors, classification standard for this kind of product organizational form is not the same [1]. Meanwhile, with the development of global economy, boundaries of large-, medium- and smallsized enterprises are constantly adjusted. In China, SMEs are divided into three types: medium-sized, small-sized and micro-sized, for which the specific standards vary according to different industries [2]. With the continuous development of small and medium-sized enterprises in China, the problems of financing difficulties faced by them have gradually emerged. The development of an enterprise needs a large quantity of capital investment. For small and medium-sized enterprises, whether they are capable of smoothly financing is the key point for their sustainable and healthy development [3].

\section{FINANCING CHANNELS FOR SMALL AND MEDIUM ENTERPRISES IN CHINA}

The financing situation for SMEs in China is not quite optimistic. In general, capital sources for SMEs can be divided into two kinds: one is the internal financing from entrepreneurs and employees of SMEs and corporate income generated during the operation of enterprises, and the other is the external financing of enterprises [4]. According to necessity of financial intermediaries, external financing can be divided into direct financing and indirect financing. The main financing method for SMEs is external financing.

\subsection{Internal Financing}

The main sources for internal financing of enterprises are the investment of the entrepreneurs at the beginning of the enterprise, and the net income generated by the operation of enterprises in the process of business. Some of the companies that prepare for list will also raise funds through issuing the internal stock (fixed stock) and then guiding the employees to purchase the original stock to assist the operation of enterprises. This way of internal financing is both low cost and low risk, but because it can only absorb funds from people who have direct interests with enterprises, and for such a limited fund range it is difficult to form scale production, hence enterprises like this cannot undertake large-scale projects [5]. If only relying on internal financing to collect funds, SMEs will not be able to collect necessary production funds in time when facing many large-scale profitable projects, which will also greatly restrict the maximization of the production capacity of SMEs. Therefore, the development of SMEs mainly depends on external financing of enterprises, and the problems of financing difficulties for SMEs are mainly embodied in external financing.

\subsection{External Financing}

The main external financing channels for SMEs in China are bank loan, bill financing, issuing stock, issuing bond and financing lease. Among them, financing lease basically can be understood as lessor by the way of instalments to obtain the right to use of lease object (object's ownership may eventually transfer or not transfer), and during the period of lease lessor shall bear the expenses of management, repairing, maintenance and other expenses of lease object. This way of financing has a long time of duration with small income, hence it cannot become the main financing way of enterprises. If a company wants to issue stocks to the society, they need to be listed on the market at first, which is a very long process. As to issue corporate bonds, according to relevant provisions in "Securities Law" and "company law", it has restricted demand for public issue of corporate bonds, such as net assets for a company limited by shares shall not be less than thirty million yuan, or net assets for a Limited Liability Company (LLC) shall not be less than sixty million yuan. These requirements are too high for SMEs, especially for those who just been 
established. To sum up, generally SMEs will choose loan from banks or financial institutions if they want to obtain external funds. In this way, they can acquire a large amount of money in a short term with a clear standard for the required remuneration (interest) of loans. SMEs can easily measure their capabilities, and then choose the most appropriate institutions to complete raising of funds. However, due to the constraints of various conditions, the financing of SMEs is not as simple as imagined.

\section{FINANCING DIFFICULTIES FOR SMALL AND MEDIUM-SIZED ENTERPRISES}

3.1 High Loan Demand from Financial Institutions for Small and Medium-sized Enterprises

Compared with large enterprises, the financial management system of SMEs is not perfect. They have questionable authenticity of book data and unreasonable product structure and organization structure, which is in company with existence of large quantities of simple and repetitive production and poor product quality. Moreover, on one hand the property right of SMEs is not clear, with unclear public and private property boundaries, on the other hand the update speed of production \& operation technology and new technology is slow. All the above-mentioned problems make it more difficult for the financial institutions to do credit evaluation, and thus reduce the credit degree of SMEs. Therefore, when a SME tries to obtain loans from financial institutions, financial institutions are often more inclined to be cautious, and hence the conditions for SMEs to obtain loans are even more severe. At the same time, when facing the conditions of funds shortage or difficulty for on-time repayment, most of SMEs hope to ease enterprise crisis through defaulting on loan and its interest, which greatly damages the reputation of SMEs, and hence contributes to the gradually increasing difficulty for enterprises to obtain loans from financial institutions.

\subsection{Lack of Capacity for mortgage and Obtaining Guarantee for Small and Medium-sized Enterprises}

When accepting a loan application, according to relevant provisions in "banking law" and "guarantee law" of China, meanwhile to reduce the risk of loans, financial institutions often require the lenders to provide assets for mortgage or find third parties to provide guarantees. Compared with large enterprises, the fixed assets of SMEs for mortgage are less. And due to the lack of evidence of business scope or operation time that can directly or indirectly prove the credibility of enterprises (operation time is not long enough, assets owned by enterprise is relatively lack, etc.), third parties will also worry about the bankruptcy of small enterprises or absconding with the money of owner in enterprises, which will cause unnecessary troubles and property loss for himself, so third parties are often not willing to provide guarantee for SMEs. Therefore, it is difficult for SMEs to obtain financing through mortgage or guarantee.

\subsection{Contradiction between Loan Demand of Small and Medium-sized} Enterprises and Financial Institutions

Because of limited scale and relatively less assets of SMEs, they are often in urgent need of funds when they seek for loans from institutions. In this premise, the loans from SMEs are often in short time, small amount and many times, and SMEs will also require financial institutions to provide loan funds in a short period of time. These features make financial institutions to repeatedly evaluate all the conditions of SMEs, which will take a lot of human resource, money and time, and greatly increase the management cost of financial institutions. As a result, financial institutions are often reluctant to lend money to SMEs. Furthermore, the repaying capability of SMEs is not as stable as large enterprises', which means once the loans are lent to SMEs and if any debt disputes (business losses, bankruptcy, incapable of on-time repayment) appears in the process of repayment, the institution will not only suffer from economic losses, but the relevant responsible person will bear relevant responsibility. Data shows that the average life of SMEs in China is 2.5 years. Under the condition that lenders are likely to disappear at any time, in order to ensure the safety and liquidity of loan funds, financial institutions are more inclined to lend loans to state-owned enterprises and large enterprises comparing to SMEs.

\subsection{Imperfectness of Legal System}

At present, China has issued series of preferential policies to support the development of SMEs, but there still exists lack of laws and regulations, and fully implementation of relevant policies. At present the relative dedicated law about SMEs in China is "Small and Medium-sized Enterprises Promotion Law", in which it is proposed that Local People's Governments shall provide financial support to SMEs according to actual situation, and pointed out that financial institutions, including People's Bank of China and commercial banks, shall provide financial support and various financial services that is suitable for the development of SMEs between Article 10th and Article 21st. However, these provisions are relatively general, and just provide a general idea without specific implementation rules, so they cannot achieve the expected effect during the implementation process. Besides of "Small and Medium-sized Enterprises Promotion Law", our country has introduced other measures to support financing of SMEs, but most of them are only guiding suggestions from macro perspective, and lack of matched concrete implementation plan or relevant supplementary laws and regulations. Therefore, the dilemma in terms of credit that SMEs are facing is still not solved. In addition, although the current relevant laws and regulations are trying to encourage financial institutions to lend loans and third parties to provide credit guarantees to SMEs by the methods of requiring financial institutions to improve credit management, promoting complete credit system of SMEs and broadening the direct financing channels for SMEs, the financial risk problem worried by financial institutions and guarantee unit is still not solved in practice. Consequently, banks are still implement severe examinations on SMEs during the process of loans, and it is still difficult for SMEs to obtain guarantees from guarantee company.

\section{Countermeasures of Financing Difficulties for Small and Medium- sized Enterprises}

\subsection{Improvement of Own Capability and Financing Conditions}

No matter for financial institutions, mortgage or third-party guarantees, when a SMEs wants to obtain more financing opportunities, the most direct and effective method is to improve its own capability through technical reform, perfecting internal organization structure of enterprise, raising level of corporate profits to accumulate more funds for the development of the future. The main reason for financial strain of SMEs is the low technical content in product, single product structure, and lack of market competitiveness, which causes incapable of contracting large-scale and high technical content projects to earn money. Therefore, the most direct and effective way to get rid of financing dilemma for SMEs is technical reform, which includes fully learning to absorb new technology, improving product technical content. Meanwhile, they should improve labor productivity, reduce product cost and enhance the competitive power of enterprises, which will improve enterprise profitability, and eventually improve the capability of self-accumulation. The accumulation of funds of enterprises is not only conducive to the future development of enterprises, but also enhancing the comprehensive strength of enterprises, which will be of great help when enterprises need to obtain external financing.

\subsection{Perfectness of Credit Guarantee System of Small and Medium sized Enterprises.}

The nature of the phenomenon that financial institutions are unwilling to lend loans to SMEs and the third parties are unwilling to guarantee SMEs is financial institutions and third parties in doubts of the credibility of SMEs. Data shows that the surviving time of SMEs is relatively short, with most of them only existing for 2 to 3 years. Therefore, the worry from financial institutions that the lent money will "not return" is very reasonable. To ease this kind of worry, it is necessary to establish and improve SMEs' credit guarantee system in China, such as the establishment of SMEs' credit files and personal credit system with clear rating standards of credit. When a SME is applying for a loan, financial institutions can rely on these credit files to determine the credit rating of this SME and whether to give the enterprise needed loans accordingly. Meanwhile when a financial institution is requiring a third party to provide loan guarantee for SMEs, the third party can determine whether 
to provide guarantee in a short period of time. In this way, it will greatly reduce the needed management cost of financial institutions and the third parties when facing loans of SME and ease the difficulties of SME in acquiring loans. In addition, the establishment of SMEs' credit guarantee system will also form the supervision and restriction on SMEs, reduce inappropriate economic behavior of SMEs, eliminate enterprises with bad credit and encourage financial institutions to lend loans to enterprises with good credit, which will eventually form a virtuous cycle and alleviate the difficulties of SMEs' financing.

\subsection{Establishment of Financial Institution Specializing in the Service for Small and Medium-sized Enterprises}

The financing needs of SMEs, which have the characteristics of small but urgent capital requirements, short period of capital loan, and more times of loans, are different from those of large enterprises. For four major stateowned Banks and commercial Banks, lending loans to SMEs has less profit, and the process of loans is not simplified compared with loans to large companies, and hence they are reluctant to lend loans to SMEs. This kind of contradiction between banks and SMEs cannot be solved by market selfadaption, and it needs the policy support from the state. Although now regulations for supporting the development of SMEs are issued by government, these rules are only a temporary support to SMEs, and have not fundamentally solve the contradiction between financial institutions (Banks) and SMEs. The Establishment of special financial institutions offering service to SMEs will simplify the existing loan procedures of financial institutions and improve transparency. In addition, government should formulate relevant specific laws and regulations on lending loans to small businesses, which will secure appropriate financing channels for SMEs from the perspective of system and provide reliable guarantee for the financing of SMEs.

\section{CONCLUSIONS}

In conclusion, financing is the most critical problem that restricts the development of SMEs in China, and the causes for this problem are varied. To solve this problem, it is demanded to make a concerted efforts by SMEs themselves, financial institutions and government.

\section{REFERENCES}

[1] Haiyan, L. 2010. Research on financing difficulties and countermeasures of SMEs [J]. Modern Business, (24), 193-194.

[2] Chaobin, X. 2002. Research on Financing Problems of SMEs [J]. Economic Management, (3), 34-38.

[3] Zhenming, Q. 2012. Study on the Difficulties of SMEs' Financing and Countermeasures [J]. Shanghai Nonferrous Metals, (33), 35-40.

[4] Aimin, Q. 2007. Analysis of SME financing channels [N]. Shanghai Securities Journal, 7, 11-30.

[5] Maoguo, C., Lu, B., Xinjun, Z. 2010. Legal Countermeasures for Bank Credit Financing of China's Small and Medium-sized Enterprises [N]. Journal of Wuhan University of Technology, (32), 188-192. 